\title{
METODY BADANIA JEZZYKA PRAWNEGO WOBEC ONTOLOGICZNEJ NATURY PRAWA
}

\author{
Maria Teresa LIZISOWA, Profesor \\ UNIWERSYTET PAPIESKI JANA PAWŁA II, KRAKÓW \\ lizis@tlen.Pl
}

\begin{abstract}
Abstrakt: Artykuł jest poświęcony metodologii badań języka ustawodawcy w aspekcie teoretycznym. Autorka proponuje interdyscyplinarne badania języka prawnego, biorąc pod uwage ontologiczną naturę prawa $\mathrm{w}$ koncepcji prawa naturalnego oraz przyjmując, że prawo naturalne pełni funkcję walidacyjną wobec prawa pozytywnego. Zakłada, że prawo jako zjawisko, które sprowadza się do obiektów językowych, utożsamia się z tekstami prawnymi (łac. lex), natomiast prawo jako relacja człowieka do rzeczy w aspekcie powinności i należności (łac. debitum) jest prawem podmiotowym(łac. ius), przy czym oba określenia dotyczą tego samego zjawiska, ujmowanego od strony treściowej lub od strony bytowo-egzystencjalnej. Autorka dokonała przeglądu prawniczych i językoznawczych kierunków badań języka komunikacji w dziedzinie prawa i przedstawiła aspekty opisu teorii języka prawnego. W opracowaniu teorii języka prawnego proponuje eklektyzm metodologiczny, do którego usposabia wieloaspektowy status ontologiczny prawa, lingwistyczny status języka prawnego oraz specyficzne odniesienie struktur języka prawnego do struktur rzeczywistości prawnej. Twierdzi, że dotychczasowe badania filozoficzne, teoretyczno-prawne i językoznawcze stworzyły warunki do integracyjnego badania poziomów języka prawnego - semantyki, syntaktyki i pragmatyki - co pozwoli scharakteryzować język prawny jako rejestr języka etnicznego w ujęciu systemowym. Twierdzi też, że teorię języka prawnego można przedstawić tylko w kontekście języka prawniczego zawodowych prawników, obsługującego obrót prawny i naukę prawa, a także w opozycji do innych języków przedmiotowych, z których język prawny czerpie zasoby form językowych do przekazania treści $\mathrm{z}$ różnych dziedzin regulacji prawnych, oraz $\mathrm{w}$ opozycji do języka ogólnego stanowiącego bazę etniczną dla języka prawnego. Postawa badacza, według autorki, powinna być otwarta na dotychczasowy dorobek badawczy filozofów, prawników i językoznawców.
\end{abstract}

\section{THE METHODS OF STUDYING LEGAL LANGUAGE IN VIEW OF THE ONTOLOGICAL NATURE OF LAW}

\begin{abstract}
The article is dedicated to methodology of studying the language of legislature in a theoretical aspect. The author proposes interdisciplinary studies of legal language, with regard to ontological nature of law in the concept of natural law and assumes that natural law serves a validative function vis-à-vis positive law. She believes that law, understood as phenomenon which comes down to linguistic objects, becomes identical with legal texts (Lat. lex), whereas law understood as a relationship between man and object in the aspect of obligation and duty (Lat. debitum) equals the rights (Lat. ius), while both the terms refer to the same phenomenon presented in substantial approach as well as well existential. The article includes a survey of legal and linguistic studies of language of communication with the field of law, and puts forward some aspects of presenting the theory of legal language. In the study of legal language theory the author
\end{abstract}


proposes methodological eclecticism, as a result of multi-aspect ontological status of law, linguistic status of legal language and specific relationship between legal language structures and legal reality structures. She claims that research carried out to date within the fields of philosophy, theory of law and linguistics, brings about the possibilities for integrative study of the levels of legal language i. e. semantic, syntactic and pragmatic - that would allow to characterise legal language as a register of ethnic language presented a systems approach. The author also states that the theory of legal language could be studied only in the context of legal language, used by professional lawyers who deal with legal practice and legal education, as well as in opposition to the other object languages, from which legal language takes its linguistic forms to communicate the content belonging to various fields of legal regulations, as well as in opposition to general language which constitutes the ethnic basis of legal language. The research approach, according to the author, should be open to the up to date achievements of philosophers, lawyers and linguists.

Słowa kluczowe: język prawny, ontologiczna natura prawa, metodologia badań języka prawnego

\section{Wstęp}

$\mathrm{W}$ artykule podejmuję temat metodologii badań języka obsługującego komunikację instytucjonalną $\mathrm{w}$ dziedzinie ustawodawstwa $\mathrm{w}$ nawiązaniu do koncepcji naukowych Bronisława Wróblewskiego, twórcy terminu język prawny. Zakładam, że celem badań jest opracowanie teorii języka prawnego w ujęciu systemowym oraz opisanie procesu i wyniku wypowiedzi ustawodawcy jako realizacji systemu znaków językowych. $\mathrm{W}$ programowaniu analiz lingwistycznych języka prawnego prezentuję niejednorodne postawy badawcze, bowiem przedmiot badań oraz cel i zakres problemów językoznawczych wpisuje się wyraźnie w filozoficzne i prawnicze koncepcje prawa. W wyborze metod badania języka prawnego uwzględniam takie aspekty filozofii prawa, prawoznawstwa i lingwistyki, które zmierzają do stwierdzenia prawidłowości ogólnych, jakimi charakteryzują się teksty aktów normatywnych, czyli wypowiedzi sformułowane w języku prawnym.

Filozofia prawa dąży do czysto teoretycznego poznania zjawiska prawa, stawiając pytania o istotę prawa i podstawy jego obowiązywania $\mathrm{w}$ świetle zasad realnego istnienia. Do różnych systemów filozoficznych nawiązuje teoria prawa, która encyklopedycznie przedstawia obiegowe pojęcia prawne, opisuje prawo fenomenologicznie, zajmuje się psychologią prawa, socjologią prawa i wykładnią przepisów prawnych. Badaniu lingwistycznemu podlega język ustawodawcy, w którym redagowane są teksty prawne. Lingwiści rozważają definicję języka prawnego w kontekście ontologicznej natury prawa. Teorię i praktykę języka prawnego postuluja opracować metodami lingwistyki w przestrzeni doświadczenia tak ustawodawcy, jak i odbiorcy aktów normatywnych, z uwzględnieniem wiedzy prawniczej, interdyscyplinarnej, bo ściśle związanej z logiką formalną. 


\section{Ontologiczna pespektywa analizy języka prawnego}

1.1. W filozofii prawa przyjmuje się, że $z$ istnieniem prawa spotykamy się wszędzie, gdzie zachodzi działanie związane z celem. Tak w przyrodzie, jak i wśród ludzi - pisał Mieczysław Albert Krapiec (1921-2008) - prawo istnieje, jeśli działanie przebiega prawidłowo. Wśród ludzi prawo bytuje w postaci relacji człowieka do rzeczy jako należność - powinność, określana łacińskim słowem debitum, niezależnie od ustawodawcy. Z tej relacji, która jest zjawiskiem naturalnym, wywodzą się prawa podmiotowe. Istotne jest zatem rozróżnienie subiektywnego prawa podmiotowego i obiektywnego prawa pozytywnego:

„Rozróżnienie prawa podmiotowego, czyli prawa pojętego jako „uprawnienie do”, oraz prawa obiektywnego, czyli ,prawa-normy”, jest dokonywane ze względu na nieco inną funkcję tego, co najogólniej określa się jako „prawo”. Oba określenia dotyczą (powinny dotyczyć) jednak tego samego bytu (znaczac co innego), o ile ujmujemy ten byt od strony bytowo-egzystencjalnej (ius) lub od strony treściowej (lex). Prawo bowiem [...] ma zdeterminowany charakter, jeśli jest ogólnie wiadome, jakie czynności (konkretnie - w jakim zakresie, kiedy itd.) należy wykonać oraz jak można o takie czynności ewentualnie się upomnieć. Zdeterminowanie dla prawa jako ius nadaje prawo jako norma - lex" ${ }^{3}$.

Istota prawa w sensie obiektywnym, twierdzi Roman Tokarczyk, jest zatem fakt racjonalno-psychiczny obecny w naturze ludzkiej jako osąd moralny kształtujący sferę powinności w działaniu ludzkim. Sens wartości w prawie pozytywnym sprowadza się do przeżyć indywidualnych, jeżeli przyjmuje się, że prawem są normy postępowania, które wyrażają wolę państwa i obowiązują ze względu na konieczność posłuchu wobec autorytetu politycznego, a także z obawy przed sankcją. Ustawodawca reguluje stosunki należności i powinności osób według własnej woli. Nie zawsze kieruje się przy tym prawami naturalnymi ${ }^{4}$. Punktem odniesienia prawa pozytywnego jest zatem aprobowane lub negowane istnienie prawa naturalnego.

1.2. W opracowaniu teorii i praktyki języka prawnego pierwszą zasada jest nawiązanie do dorobku naukowego głównych nurtów myśli prawniczej, którymi są: imperatywizm oparty na koncepcji prawa naturalnego lub pozytywizmu prawniczego, a także realizm prawniczy.

W obrębie imperatywizmu prawniczego badacze traktuja prawo jako formę powinności $\mathrm{w}$ pozaempirycznej sferze istnienia, lecz oddziałującą na świat realny, a prawoznawstwo uważają za naukę o normach prawnych. W podręczniku akademickim

\footnotetext{
${ }^{3}$ Zob. Krapiec 1975: 25-32. Autor przedstawil aspekty teoretyczne bytowego charakteru prawa w ogólności oraz bytowego charakteru normy prawnej.

${ }^{4}$ Zob. Tokarczyk 2004: 170.

${ }^{5} \mathrm{~W}$ teorii prawa istnieja kontrowersje co do ontologii prawa. Prawo traktuje się jako klase obiektów jednorodnych, takich jak przeżycia psychiczne, zachowania ludzi lub obiekty językowe, albo wymienia się różne klasy obiektów jako niezbędne składniki prawa, zob. Gizbert-Studnicki 1986: 8. Autor powołuje się na dwie różne wersje koncepcji filozoficznych - Wiesława Langa i Jana Woleńskiego.
} 
można przeczytać, że w koncepcji prawa naturalnego, czyli w jusnaturalizmie, uznaje się istnienie dwóch porządków normatywnych - naturalnego i pozytywnego - przy czym prawo naturalne pełni funkcję walidacyjną wobec prawa pozytywnego ${ }^{6}$. Autorzy przyjmują, że z koncepcji prawa naturalnego wywodzi się „katalog praw podmiotowych”, a także „etyczne teorie słusznego prawa” jako wzoru dla ,idealnego modelu prawa pozytywnego" (Bator et al. 2006,40). Podkreślają też, że pozytywizm prawniczy jest we współczesnym prawoznawstwie nurtem niejednolitym - istotne jest to, że wszystkie prądy tego kierunku w zasadzie uznaja, iż ,prawo jest wyrazem woli ustawodawcy” oraz że prawo ,jest wyrażone w tekście” (Bator et al. 2006 58).

Realizm prawniczy - piszą dalej autorzy podręcznika - traktuje prawo jako „element realny, w opozycji bytu i powinności, umiejscowiony po stronie bytu i poddający się badaniu tak jak każdy inny fakt społeczny" (Bator et al. 2006 67). Twierdza, że realistyczny nurt myśli prawniczej jest ukierunkowany na badanie prawa jako zjawiska społecznego, które powstaje w interakcji ustawodawca - społeczeństwo. W wyniku działania komunikacyjnego powstaja akty normatywne - kodeksy, ustawy i rozporządzenia - stanowiące byt prawa.

1.3. Odnosząc badanie nad językiem prawnym do ontologicznej natury prawa, należy uwzględnić, w jaki sposób bytowy charakter prawa jako relacji interpersonalnej wyraża się $\mathrm{w}$ prawie stanowionym. Rys. 1. przedstawia zjawiska realnego istnienia prawa jako faktu relacji interpersonalnej, z której wywodzą się prawa podmiotowe, a także zjawiska prawa jako abstrakcyjna rzeczywistość prawna regulowana abstrakcyjnymi normami prawnymi oraz jako realna rzeczywistość prawna, w której normy prawne obowiązuja jako prawo w obrocie.

\section{Rys. 1. Prawo jako zjawisko bytowe.}

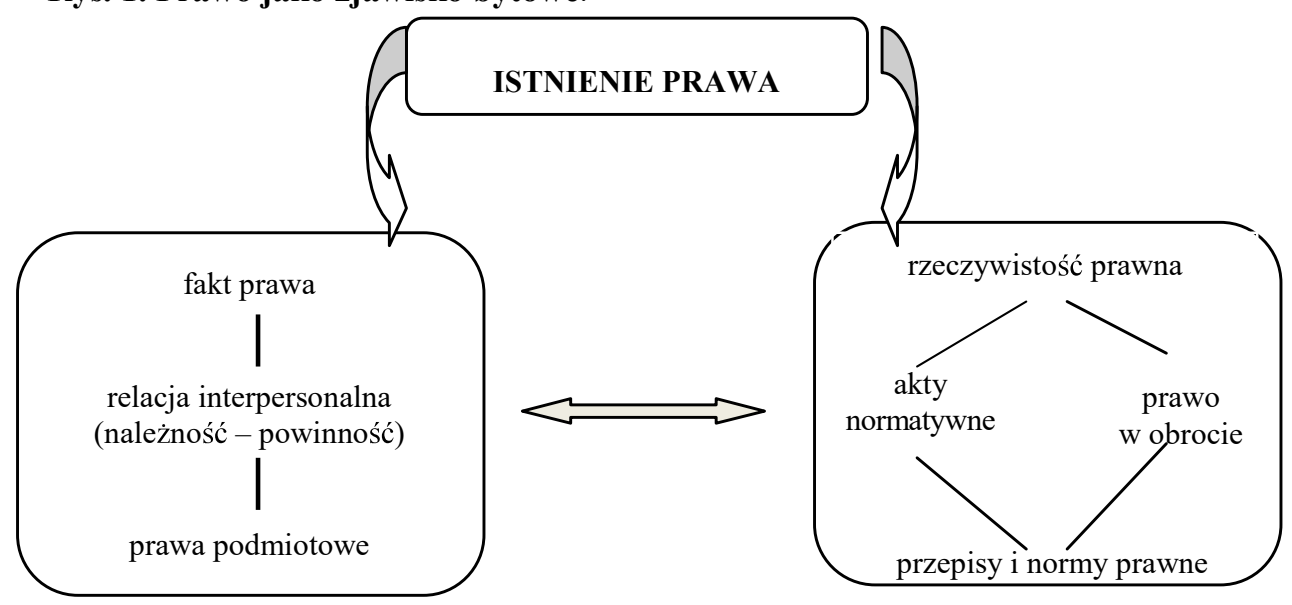

\footnotetext{
${ }^{6}$ Zob. Charakterystyka nauk prawnych dla celów dydaktycznych: Bator [i in.] 2006: 13-72.
} 
1. W lingwistycznym opisie języka prawnego uwzględnia się główne założenia imperatywizmu i realizmu prawniczego. Jeżeli byt prawa nie wyczerpuje się w klasie obiektów jednorodnych ontologicznie, a język komunikuje naturę prawa, słuszne jest odróżnianie języka ustawodawców od języka obrotu prawnego, jakie wprowadził Bronisław Wróblewski, wyodrębniając język prawny komunikacji instytucjonalnej w dziedzinie prawa ustanowionego oraz język prawniczy komunikujący prawo w obrocie na tle funkcjonalnych odmian języka etnicznego ${ }^{7}$. Zob. rys. 2.

2.

Rys. 2. Odmiany funkcjonalno-semantyczne języka etnicznego.

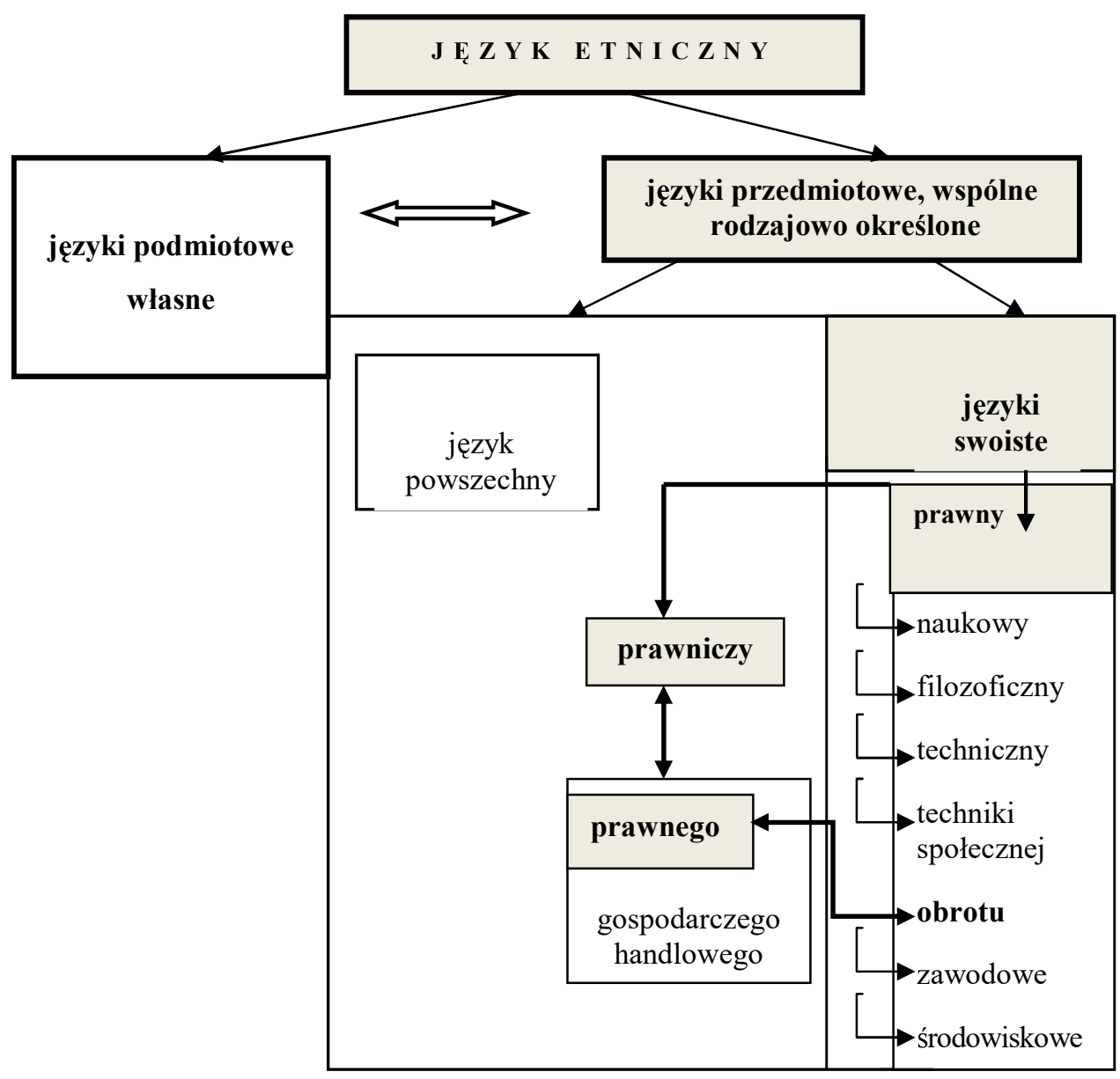

${ }^{7}$ Zob. Wróblewski 1948:30. Autor podaje następującą charakterystykę obrotu: „Obrót dotyczy stosunków w takiej lub innej dziedzinie zachowania się i oznacza powtarzające się czyny i postępowanie, posiadające określony przedmiot. Owo zachowanie się jest odcinkiem życia, który, pomiędzy innymi, wytwarza pewne zwyczaje, szablony, które obejmują również język”, s. 3 
Uczony ten dokonał charakterystyki odmian języka obsługującego dwie sfery funkcjonowania prawa jako lex. Uwzględniał przy tym, że w reglamentowanej przez ustawodawcę rzeczywistości prawnej obowiązują prawa podmiotowe wirtualnych osób, ujmowane jako ius. W klasyfikacji funkcjonalno-sematycznej języków przeciwstawiał podmiotowy język własny (osobowy) wspólnemu językowi przedmiotowemu (pozaosobowemu) ${ }^{8}$. Język prawny zaliczył do odmiany języków wspólnych, rodzajowo określonych, jako język różny od języka powszechnego w codziennym użyciu praktycznym, a także różny od innych języków swoistych, takich jak naukowy, filozoficzny, techniczny, techniki społecznej, obrotu, języki zawodowe i środowiskowe? Przyjmował strukturalistyczne rozumienie systemu języka, lecz wskazywał zarazem na funkcjonowanie systemów form i znaczeń jednostek języka prawnego w użyciu.

\section{Prawnicze i językoznawcze kierunki badań języka prawnego}

2.1. Termin język prawny w rozumieniu Bronisława Wróblewskiego został zaakceptowany $w$ naukach prawnych i języ2qkoznawczych ${ }^{10}$. Prawnicy i językoznawcy zakładają że mowa ludzka to mówienie i rozumienie utrwalone w tekście, a teksty moga być reprodukowane, lecz nie są bezpośrednią podstawą innych tekstów. Przyjmują tezę, że systemem wyrazów i reguł ich łączenia, wyabstrahowanym z zapamiętanych tekstów, jest język jako twór mowy społeczny i abstrakcyjny. Wszak Tadeusz Milewski uczył, że ,język zawarty jest w tekstach zapamiętanych i zapisanych jako ich składnik, który można wyabstrahować, wyodrębnić,"11. Według Stanisława Grabiasa teksty to ciagi zachowań językowych, „których postać zależy od tego, kto mówi, do kogo, w jakiej sytuacji i w jakim celu" 12 . Teksty prawne bada się więc jako dyskurs zanurzony w uwarunkowaniach społecznych. Realizacje tekstowe dyskursu powodują bowiem

\footnotetext{
${ }^{8}$ Zob. Wróblewski 194: 10-11. Ważniejsze pozycje literatury naukowej wykorzystane przez uczonego nawiązuja do językoznawczych do prac Jana Rozwadowskiego (1867-1935), Jerzego Kuryłowicza (1895-1978), także do teorii logicznych Bertranda Russela(1872-1970), Alfreda Tarskiego (1901-1983) i Kazimerza Ajdukiewicza (1890-1963), do nauki prawa Leona Petrażyckiego (1867-1931) i Hansa Kelsena (1881-1973) oraz do ówczesnej wiedzy filozoficznej Bergsona (1859-1941), psychologicznej i socjologicznej na temat funkcji języka w opracowaniu Marii Ossowskiej (1896-1974).

${ }^{9}$ Zob. Wróblewski 1948: 30-36. Znane w historii językoznawstwa klasyfikacje języków miały u podstaw kryteria genetyczne, geograficzne lub typologiczne.

${ }^{10}$ Zob. Petzel, 2006: 153-163. Autor uzasadnia, że język prawny nie jest rejestrem języka w interpretacji rygorystycznej, lecz ze względu na pola tematyczne leksyki co najwyżej w rozumieniu liberalnym. Dyskusyjne jest także uznanie języka prawnego za rejestr w sensie teoretyczno-lingwistycznym, bo nie jest do końca uzasadnione jego usytuowanie tak w sferze systemu i kompetencji (langue, competence), jak i w sferze użycia (parole, performance). Brak jest bowiem badań potwierdzających odmienne od języka powszechnego właściwości semantyczne. Por. Gizbert-Studnicki 1979: 49-60. Zob. Pieńkos 1999: 83-85. Autorzy przyjmuja, że język prawny wyróżnia się jednak od potocznego języka naturalnego znaczeniem niezbędnym do regulacji prawnej.

${ }^{11}$ Zob. Milewski 1972: 7.

${ }^{12}$ Zob. Grabias 1994
} 
kombinacje i transformacje środków językowych, które sprowadzają się do powstania subsystemów języka we wzorcach tekstowych gatunków wypowiedzi. Ze względu na gatunki wypowiedzi, strukturę tekstu, składnię, językowe środki wyrazu i semantyczną organizację słownictwa odkrywa się w tekstach prawnych cechy stylu urzędowego, które mają wpływać na postępowanie ludzi pozostających w stosunkach społecznych, gdyż nakazy postępowania są w nich motywowane czynnikami ze sfery władzy.

2.2. Przegląd kierunków badań nad językiem prawnym w naukach humanistycznych zamieścił Andrzej Malinowski w książce Polski język prawny, badając język prawny dla celów wykładni prawniczej. Według A. Malinowskiego należy dokonać analizy tekstów prawnych w kategoriach logicznych, albo przez porównanie struktur języka prawnego ze strukturami języka potocznego, ponieważ metody obu kierunków badań logicznych języka prawnego zmierzają do ,uporządkowania teoretycznego problematyki normy prawnej, wykładni prawa i wnioskowań prawniczych", wzajemnie się uzupełniaja, a ponadto mogą być z powodzeniem stosowane obok metod lingwistycznych służących opisowi statusu języka prawnego ze względu na występujące w nim różnice w stosunku do potocznego języka etnicznego ${ }^{13}$. Prawnicze i lingwistyczne kierunki badań języka prawnego przedstawia tabela 1 .

Tabela 1. Dyscypliny humanistyki badające język prawny.

\begin{tabular}{|c|c|}
\hline \multicolumn{2}{|c|}{ kierunki badań języka prawnego } \\
\hline prawnicze & lingwistyczne \\
\hline $\begin{array}{l}\text { rekonstrukcjonizm } \\
\text { deskrypcjonizm } \\
\text { semiotyka logiczna }\end{array}$ & $\begin{array}{l}\text { językoznawstwo ogólne } \\
\text { strukturalizm i funkcjonalizm } \\
\text { semiotyka językoznawcza }\end{array}$ \\
\hline \multicolumn{2}{|c|}{$\begin{array}{l}\text { SEMIOTYKA LOGICZNA I LINGWISTYCZNA } \\
\text { 1) semantyka: głównie właściwości słownictwa, znaczenia zwrotów i zdań normatywnych, } \\
\text { definicje legalne, } \\
\text { 2) syntaktyka: predykaty i argumenty zdań normatywnych, struktura wewnętrzną zdań } \\
\text { normatywnych, powiazania między czéściami aktu normatywnego } \\
\text { 3) pragmatyka: funkcje pełnione przez wypowiedzi języka prawnego i sposoby posługiwania się } \\
\text { językiem prawnym w ujęciu socjologicznym lub psychologicznym }\end{array}$} \\
\hline
\end{tabular}

Stanowiska badawcze prawników w płaszczyźnie językowej są warunkowane metodami logicznymi rekonstrukcjonizmu, deskrypcjonizmu i semiotyki logicznej. Lingwistyczne kierunki badań historii i współczesnych cech języka prawnego uwzględniają założenia metodologiczne językoznawstwa ogólnego, strukturalizmu i funkcjonalizmu oraz semiotyki językoznawczej.

${ }^{13}$ Zob. Malinowski 2006: 18. 
Rekonstrukcjonizm jest oparty na założeniach logiki formalnej. Badania zmierzają do opracowania definicji logicznych pojęć i do usuwania wieloznaczności zdań metodą rekonstrukcji formalnej. Badanie rachunków zdań i definiowanie pojęć ma na celu odkrycie logicznej struktury języka prawnego, przydatne w analizach prawniczych. Badacz szuka odpowiedzi na pytania o status logiczno-ontologiczny zdań normatywnych według zasad logiki deontycznej za pomocą sformalizowanego rachunku zdań z użyciem zwrotów: jest obowiazkowe, jest zakazane, jest dozwolone, jest indyferentne. Autor uwzględnia jednak dane logiki deontycznej, że system taki nie jest wolny od paradoksów

Z kolei deskrypcjonizm neguje przydatność logiki w wykładni prawniczej. W nurcie deskrypcjonizmu reguły użycia języka uwzględniają nieostrość i wieloznaczność wyrażeń w kontekście. Celem badań są właściwości semiotyczne języka prawnego. Badania semiotyczne obejmują: 1) semantykę, tj. głównie właściwości słownictwa, znaczenia zwrotów normatywnych i definicje legalne; 2) syntaktykę, a więc predykaty i argumenty zdań normatywnych, strukturę wewnętrzną aktów normatywnych, powiązania między częściami aktu normatywnego, strukturę systemu i powiązanie wewnątrzsystemowe aktów normatywnych; 3) pragmatykę, czyli funkcje pełnione przez wypowiedzi języka prawnego, a także sposoby posługiwania się językiem prawnym w ujęciu socjologicznym i psychologicznym. Deskrypcjoniści opisują znaczenie i budowę wyrażeń języka prawnego i oddziaływanie wypowiedzi sformułowanych w tym języku na adresatów. Badaniu deskrypcjonistycznemu przepisów prawnych podlegają powiązania formalne i funkcjonalne zbiorów wypowiedzi w tekście prawnym, które prowadzą do merytorycznej wykładni tekstów prawnych ${ }^{14}$, jak również do systemowych uwarunkowań interpretacyjnych ${ }^{15}$.

W nawiązaniu do logicznych teorii analizy języka w polskiej teorii prawa wypracowano strukturę i koncepcję znaczenia normy prawnej. Strukturę normy przedstawił Stefan Grzybowski ${ }^{16}$. Do analizy norm Jerzy Wróblewski, zastosował emotywną koncepcję znaczenia, wiążąc funkcję normy z jej znaczeniem, podobnie jak Kazimierz Ajdukiewicz (1890-1963) zdanie i sąd. Z treści przepisów prawnych teoretycy prawa odtwarzali normy prawne wysłowione oraz warunki i okoliczności ich obowiązywania. Konceptualizacji poddali podmiotowe działania adresatów norm w warunkach i okolicznościach obowiązywania norm. Opisali relatywizację znaczenia zwrotów językowych wchodzących w skład normy do normy jako całości. Uzasadnili logicznie, że zwroty te mają sens dlatego, że są częściami normy ${ }^{17}$. Dzięki rekonstrukcji formalnej zdań normatywnych i zdefiniowaniu pojęć prawniczych metodą logiki formalnej, a także dzięki opracowaniu zasad interpretacji przepisów prawnych według derywacyjnych reguł rekonstrukcji norm prawnych zostały stworzone warunki do badań filologicznych.

\footnotetext{
${ }^{14}$ Zob. Ziembiński 1966, rozdz. V., rozdz. VIII $§ 2$.

${ }^{15}$ Zob. R. Sarkowicz 1998: 263 i n.

${ }^{16}$ Zob. Grzybowski 1961.

${ }^{17}$ Zob. Wróblewski 1959, Opałek 1974, por. Woleński 1972.
} 
2.3. Metody badań lingwistycznych nad statusem języka prawnego zależą od przyjętych konwencji i celu. Myślą przewodnią jest wyodrębnienie takich cech ważnych, a pominięcie cech nieistotnych mowy ustawodawcy, które mają charakter społeczny w przeciwieństwie do indywidualnego procesu mówienia, mają też charakter abstrakcyjny w przeciwieństwie do konkretnych procesów mówienia i zrozumienia oraz $\mathrm{w}$ przeciwieństwie do konkretnego tekstu, a także mają trwałe istnienie w czasie $\mathrm{w}$ przeciwieństwie do przemijania procesu mówienia i zrozumienia ${ }^{18}$.

Przedmiotem badań języka prawnego metodami językoznawstwa ogólnego jest leksyka i gramatyka zawarta $\mathrm{w}$ dawnych i współczesnych tekstach prawnych, z których można wyabstrahować, jak system etnicznego języka ogólnego został przystosowany do wyrażania treści normatywnych. Badanie leksyki zmierza do opisu prawniczych idiomów. Obejmuje także analizę struktury pól leksykalno-semantycznych terminów prawnych, ich ewolucję, mechanizmy wzbogacania zasobu prasłowiańskiego w języku polskim w wyniku rodzimych procesów derywacji morfologicznej, syntaktycznej i neosemantyzacji ${ }^{19}$. Badaniom poddawane sa podstawowe terminy prawne $\mathrm{w}$ dobie staropolskiej na tle ogólnosłowiańskim z odniesieniami do współczesności ${ }^{20}$. W systemie semantycznym słownictwo współczesnego języka prawnego podlega opracowaniu w związku z rekonstrukcjonistyczną wiedzą prawniczą na temat definicji logicznych pojęć prawnych $^{21}$. W składni bada się realizację wzorca normy prawnej w zabytkach ustawodawstwa $\mathrm{i}$ we współczesnych aktach normatywnych. W systemie stylistycznym analizie lingwistycznej podlegają takie znaki językowe, które są używane w funkcji pozajęzykowej, dyrektywalnej.

W strukturalizmie interpretuje się wszelkie elementy języka we wzajemnym powiązaniu $\mathrm{w}$ ramach systemu abstrakcyjnych struktur językowych wjakimś stopniu autonomicznych. Język jest traktowany jako byt materialny, który można opisać jako system znaków czy form wyrażania. Lingwistyka strukturalna koncentruje się na badaniu abstrakcyjnej struktury formalnej języka sprowadzając język do słownika jednostek pierwotnych i do reguł tworzenie tekstów z tych jednostek. System znaków języka bada się w stosunkach opozycji pod względem wartości i funkcji na poziomie wyrażania oraz na poziomie kontekstu nieobecnego. Celem badań jest odkrycie struktur języka prawnego (langue), w strukturach tekstu prawnego tworzonego w danym języku etnicznym (parole). Do badania struktury języka mogą być wykorzystane modele składniowe tworzone metodą gramatyki generatywnej. Badania strukturalne korespondują więc $\mathrm{z}$ logicznym rekonstrukcjonizmem.

\footnotetext{
${ }^{18}$ Przegląd badań nad językiem prawnym obejmuje wybrane problemy badawcze zmierzające do opracowania ogólnej teorii języka prawnego. Autorka nie ma na uwadze zainteresowań badaczy, podejmujących odmienną analizę języka obsługującego dziedzinę prawa. Poza przedmiotem badań pozostaje opis idiolektów zawodowych.

${ }^{19}$ Zob. Zajda 2001.

${ }^{20}$ Zob. Malinowska 2012, Szczepankowska 2004, Lizisowa 1995, 2000.

${ }^{21}$ Zob. Choduń 2007. Autorka analizuje terminologię, związki frazeologiczne i zestawienia wielowyrazowe oraz wpływ sytuacji komunikacyjnej na dobór słownictwa w tekstach aktów prawnych.
} 
2.4. Koncepcje badań języka prawnego jest ukierunkowana na znaki języka jako narzędzia komunikacji oraz na język jako właściwość ludzkiej mowy. Wspólną perspektywę badań prawniczych i lingwistycznych przedstawia semiotyczna teoria znaku, zajmująca się typologia, postacią oraz rolą jaką pełnią znaki charakterystyczne dla języka prawnego w procesie porozumiewania się ustawodawcy ze społeczeństwem. Bada się zjawiska warunkujące porządek w użyciu znaków języka $\mathrm{z}$ uwzględnieniem kategorii mówiącego i adresata w różnych sytuacjach społeczno-kulturowych oraz z uwzględnieniem celu konwersacyjnego uczestników dyskursu. Funkcjonalne badania są skierowane na wzajemne oddziaływanie w komunikacji językowej formy i funkcji znaków językowych, między którymi nie ma prostych relacji. Różne aspekty organizacji środków językowych przedstawiają użycie danej formy jako natężenie informacyjne składników zdania i tekstu w związku z kontekstem. W centrum zainteresowania pojawia się tekst prawny jako forma działania społecznego. Funkcjonowanie języka prawnego w obiegu społecznym bada się metodami socjolingwistyki ${ }^{22}$. Uwzględnia się także psychologiczne warunki funkcjonowania języka, przyjmując, że istnieja zintegrowane w mózgach struktury ludzkiego myślenia o rzeczywistości świata pozajęzykowego, które można poznać poprzez obserwację reguł językowych, którymi faktycznie ludzie się z sobą komunikują ${ }^{23}$. Różnorodność paradygmatów naukowych w badaniach nad językiem prawnym rewiduje jednostronne podejście do lingwistycznego statusu zjawiska języka ${ }^{24}$.

2.5. Metody lingwistyczne analiz języka prawnego ocenia A. Malinowski z pozycji przydatności wyników badań dla prawnika. Na pierwszym miejscu stawia inżynierię lingwistyczną zajmującą się systemami rozpoznawania i generowania mowy wjęzyku naturalnym w powiazaniu z programem pozyskiwania wiedzy prawniczej oraz maszynowe tłumaczenie tekstów metodami językoznawstwa matematycznego i statystycznego. Empiryczne badania języka prawnego mają dla prawnika o tyle sens, o ile są przydatne w wykładni prawniczej do wykrycia prawidłowości występujących w zbiorze tekstów legislacyjnych, przydatnych w wykładni prawniczej ${ }^{25}$.

Rzecz oczywista, że zainteresowania badaczy w dyscyplinach naukowych prawoznawstwa i lingwistyki są różne. Prawnicy badają prawo poprzez język tekstów prawnych, lingwiści badają język prawny w perspektywie ontologicznej koncepcji prawa ${ }^{26}$. W lingwistycznej metodologii badań języka prawnego uwzględnia się zasadnicze zdobycze nauk o prawie, a więc językoznawca wpisuje się w nurty filozofii prawa i prawoznawstwa. Dla językoznawcy ważny jest ten kierunek badań prawoznawczych, który dotyczy prawa jako zjawiska językowego.

\footnotetext{
${ }^{22}$ Socjolingwistyczny kierunek badań języka prawnego zapoczątkował Tomasz Gizbert-Studnicki, zob. Gizbert-Studnicki 1986.

${ }^{23}$ Zob. Grucza 1997: 16; por. Wróblewski 1948: 6. Pisząc o funkcjach języka autor powołuje się na artykuł M. Ostrowskiej, Stowa i myśli, „Przegląd Filozoficzny” 1931.

${ }^{24}$ Język prawny jest przedstawiany jako: język rodzajowy, język specjalistyczny, rejestr językowy, język prawodawcy/ustawodawcy, idiolekt racjonalnego prawodawcy, a nawet jako tekst przepisów prawnych czy kod słowny, zob. Malinowski 2006: 21.

${ }^{25}$ Por. Petzel 1999: 110 i n.

${ }^{26}$ Pomijam cele praktyczne, $\mathrm{z}$ których najważniejszy to tłumaczenie tekstów prawnych.
} 
Przyjmując, że ludzie posługujący się danym językiem podobnie reagują na jego znaki, językoznawca traktuje też język prawny jako właściwość językową tekstów prawnych, charakteryzujących się swoistym zasobem formuł i modeli języka etnicznego przyswajanych przez ich powtarzanie z pewnymi innowacjami, które są tworzone w używaniu języka przez analogię do prawniczych modeli norm prawnych ${ }^{27}$. Zmierza do odtworzenia systemu form znaków językowych, które odnoszą się do relacji należność-powinność (łac. debitum). Metodą dedukcji bada odniesienie faktów językowych do faktu prawa jako prawa podmiotowego w stosunkach prawnych tetycznych (łac. ius), a także rozważa współzależność faktów językowych z faktami rzeczywistości prawnej, jaką reglamentuje ustawodawca w prawie stanowionym, rozumianym od strony treściowej (łac. lex).

2.6. Badaniom językoznawczym podlegają systemowe cechy gatunkowe języka prawnego zawarte $\mathrm{w}$ tekstach prawnych. Zasadniczo przyjmuje się, że specyfiką gatunkową języka prawnego jest normatywność jako właściwość kategorialna. Normatywność determinuje reguły tekstu na płaszczyźnie semantycznej. Bada się wówczas odniesienie jednostek języka wskazujących na wybrany kontekst społeczny nie bezpośrednio, lecz poprzez siatkę pojęć prawniczych w danej kulturze prawnej. Przyjmuje się, że rzeczy oznaczone tekstem wskazuja na kontekst zjawisk społecznych, które Jürgen Habermas określił jako zjawiska świata zapośredniczone między faktycznością a obowiązywaniem ${ }^{28}$.

Lingwista analizujący tekst prawny odnosi działania adresatów do abstrakcyjnej rzeczywistości prawnej w świecie tekstu prawnego i zarazem do prognozowanej przez ustawodawcę sytuacji, jaka faktycznie może zaistnieć wrzeczywistym świecie ${ }^{29}$. Przyjmuje, że struktura normy prawnej obejmuje dyspozycję co do postępowania osób oraz hipotezę co do warunków tego postępowania. Analizując przepis prawny, opisuje składniki referencyjne zdań normatywnych denotujące argumenty osobowe (adresata normy prawnej lub recipienta nakazanego przez normę działania) oraz argumenty rzeczowe (przedmioty podlegajace regulacji prawnej). Opisuje także predykaty modalne orzekające o charakterze normatywnym czynności adresatów i recipientów.

Teoretyk języka bierze pod uwagę ontologiczny status prawa w ujęciu imperatywizmu jako formę powinności w dwóch porządkach normatywnych: naturalnym i pozytywnym - jako prawo wyrażone w tekście. Odnosi zarazem formy znaków języka do prawa jako zjawiska społecznego w ujęciu realizmu prawniczego, które powstaje w interakcji ustawodawca-społeczeństwo. Badaniom podlegają akty mowy, w których badacz odkrywa prawidłowości funkcjonowania języka prawnego $\mathrm{w}$ społeczeństwie i relacje pomiędzy językiem a jego użytkownikami ${ }^{30}$. Znaki języka etnicznego odnosi tak do norm prawnych zapisanych w tekście prawnym, jak i do reglamentowanej przez ustawodawcę

27 Struktura normy prawnej według Stefana Grzybowskiego, zob. Grzybowski 1961. Zob. też. postać słowna i struktura norm postępowania, Ziembiński 2002: 114-120. Szerzej na temat tekstu prawnego jako produktu i procesu komunikacji językowej oraz na temat normy prawnej jako jednostki wypowiedzeniowej w tekście prawnym, zob. Lizisowa 2006: 33-43.

${ }^{28}$ Zob. Habermas 2005: 40.

${ }^{29}$ Zob. na temat tekstu prawnego jako znaku w języku prawnym Lizisowa 2008: 381-400.

${ }^{30}$ Zob. zgodnie z modelem języka przedstawionym przez Karla Bühlera w jego książce Teoria języka, Bühler 2004: 29. 
rzeczywistości prawnej, w której normy te obowiązuja. W związku z tym Maciej Zieliński przyjmuje, że język prawny jako twór społeczny i abstrakcyjny jest sumą wyabstrahowanego $\mathrm{z}$ przepisów prawnych systemu wyrazów i reguł ich łączenia o tematyce prawnej oraz systemu wyinterpretowanych z przepisów prawnych norm prawnych ${ }^{31}$.

\section{Semiotyczne aspekty badania języka prawnego}

3.1. Język prawny $\mathrm{w}$ doświadczeniu ustawodawcy i interpretatora jest poddany badaniom interdyscyplinarnym, przy czym eklektyzm metodologiczny, polega na łączeniu w jedna, choć niespójną całość, różnych teorii, koncepcji, tez i pojęć wielu kierunków badawczych, które służą stanowieniu norm prawnych. W nawiązaniu do postulatów Bronisława Wróblewskiego metodami lingwistyki można badać: 1) status podmiotu posługującego się językiem jako narzędziem myślenia, rozumienia i wyrażania myśli z pozycji ustawodawcy; 2) sposób mówienia ustawodawcy; 3) składniki semantyczne języka, technikę językową i styl; 4) odniesienie znaków języka prawnego do pojęć i sądów normatywnych wyrażanych językowo w postaci pisemnie sformułowanych przepisów prawnych; 5) odniesienie znaków języka prawnego do rzeczywistości prawnej w świecie pozajęzykowym; 6) relacje między rzeczywistością prawną komunikowaną w przepisach prawnych a idealnymi modelami przedstawiającymi konstrukty mentalne norm prawnych.

3.2. Język prawny w przestrzeni doświadczenia ustawodawcy bada się na poziomie pragmatycznym i tekstologicznym. W opisie aspektów komunikacji językowej między ustawodawcą a adresatami norm prawnych prawnicy i językoznawcy odwołują się do teorii aktów mowy Johna L. Austina (1911-1960). Akt stanowienia prawa traktuje się jako performatywny akt mowy o charakterze ceremonialnym, posiadający moc sprawcza. Przyjmuje się, że stanowienie prawa jest działaniem językowym ustawodawcy, w wyniku którego powstają akty ustawodawcze ${ }^{32}$. Badanie sprawczego działania aktów mowy wymaga zreformowania referencyjnej teorii znaczenia zdań, opartej na analizie sądów i wykazania, jak wyrażenia języka zmieniają swoje odniesienie i sens w zależności od używania ich przez nadawcę ${ }^{33}$. Wymaga także instrumentalnego badania wypowiedzi jako działań językowych (Ludwig Wittgenstein 1889-1951, John Searle 1932-). Za składnik znaczenia wypowiedzi uznaje się tzw. znaczenie użycia, uzależniające jej interpretację od okoliczności towarzyszących.

Komunikowanie się władzy ustawodawczej z obywatelami wymaga odpowiedniego konstruowania struktury tekstu, które bada się metodami tekstologii, przyjmując charakterystyczne dla tej dyscypliny naukowej terminy i pojęcia superstruktury, makrostruktury i mikrostruktury.

\footnotetext{
${ }^{31}$ Zob. Zieliński 1972: 7 i n.

${ }^{32}$ Zob. Austin 1993: 550-560 oraz 692-708. W fenomenologii lingwistycznej John L. Austin przedstawił teorię performatywów i konstatywów oraz opracował klasy mocy illokucyjnych.

33 Performatywność i modalność wypowiedzi ustawodawcy w polskich tekstach prawnych, zob. Lizisowa 2009: 19-36.
} 
Superstruktura jest semiotycznym wzorcem tekstu i abstrakcyjnym planem tekstu. Schemat superstruktury, obejmujący globalną organizację formy językowej, jest zorientowany na cel komunikacyjny. Makrostruktura reprezentuje temat globalny tekstu, a także obejmuje globalną organizację treści ${ }^{34}$. Natomiast mikrostruktura stanowi rodzaj schematu segmentów tekstowych, którym przypisuje się skonwencjonalizowane kategorie tekstowe. Model tekstu prawnego w perspektywie teorii tekstu przedstawia rys. 3 .

Rys. 3. Model tekstu prawnego

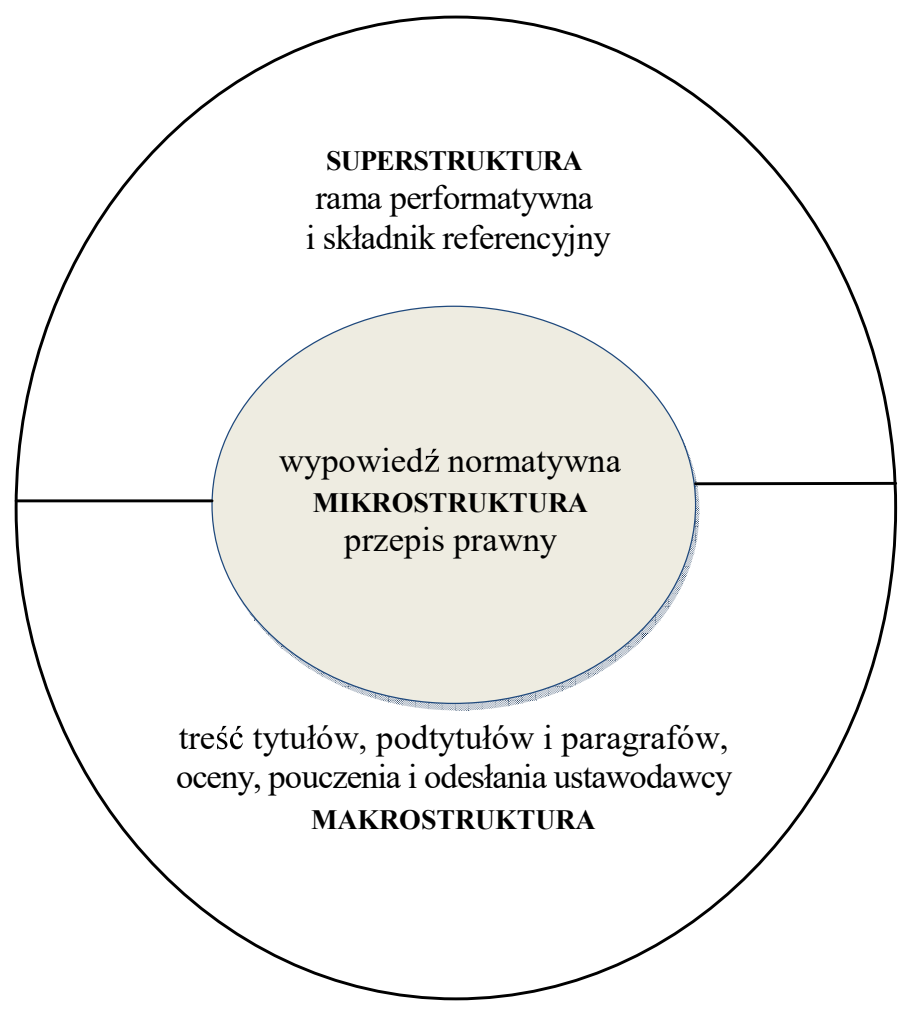

$\mathrm{Z}$ przedstawionego modelu wynika, że $\mathrm{w}$ superstrukturze tekstu aktu normatywnego opisuje się performatywną ramę metatekstową, która zawiera presuponowany składnik dyrektywalny oraz zbiór zdań przepisów prawnych, uporządkowanych w jednostki tekstowe i stanowiących składnik referencjalny. Rama

\footnotetext{
34 Typologizacja zdarzeń tekstowych została opracowana według teorii dyskursu zaproponowanej przez Annę Duszak, zob. Duszak 1998: 173-241.
} 
metatekstowa jest symbolicznym znakiem werbalnym stanowienia aktu normatywnego [np. formuła performatywna w jest zapisana w preambule Konstytucji RP: my, Naród Polski - wszyscy obywatele Rzeczypospolitej [...] ustanawiamy Konstytucję Rzeczypospolitej Polskiej jako prawa podstawowe dla państwa, ogłoszonej z datą promulgacji: Dz. U. z dnia 16 lipca 1997 r. ], albo znakiem niewerbalnym o charakterze indeksu [np. promulgacja Ustawy o prawie autorskim i prawach pokrewnych z dnia 4 lutego $1994 \mathrm{r}$. ogłoszonej w Dz. U. 1994 r. Nr 24 poz. 83 wskazuje wprost na jej stanowienie]. Słowny lub presuponowany składnik performatywny wyraża wolę ustawodawcy, której siła illokucyjna jest mierzona w kategoriach skuteczności. Jej rezultatem perlokucyjmym jest sterowanie działaniem urzędów i obywateli. Poszczególne przepisy prawne to referncjalne wykładniki norm prawnych. Składają się $z$ dyspozycyjnych zdań normatywnych o charakterze powinnościowym oraz ze zdań opisowych przedstawiających warunki i okoliczności obowiązywania dyspozycji.

Makrostruktura jest uporządkowana według planu tekstu i podporządkowana supersrukturze. Plan tekstu jest rusztowaniem dla pojęciowej struktury całości. Badacz dochodzi do globalnego znaczenia aktu normatywnego przez wyabstrahowanie głównej linii semantycznej tekstu. ${ }^{35}$. Zasadniczym sygnałem strategicznym jest tytuł, tytuły rozdziałów i podrozdziałów. Sygnały strategiczne, a także różnego rodzaju oceny, pouczenia i odesłania do innych aktów stanowienia prawa, tworzą plan tekstu, są rodzajem streszczenia, lecz nie odtwarzają semiotycznego charakteru aktu normatywnego.

Semiotyczną naturę tekstu prawnego i jego definiowalność jako znaku języka prawnego reprezentuje model mikrostruktury, jaki obejmuje układ najistotniejszych cech i założeń tekstowych wbudowanych tak w superstrukturę, jak i w makrostrukturę. Nie obejmuje części makrostruktury nieistotnych dla wypowiedzi prawnej, mimo że istotnych dla jej znaczenia. Mikrostruktura tekstu prawnego jest $\mathrm{w}$ planie wyrażania przepisem prawnym, a w planie treści normą prawną.

3.3. Analizując sposób mówienia ustawodawcy, prawnicy i lingwiści nawiązują do logistyki. Koło Wiedeńskie, istniejące od 1922 roku, zajmowało się analizą sądów, czyli badaniem ludzkiego poznania i sposobu komunikowania się ludzi między sobą w języku naturalnym podmiotowo-orzecznikowym. Z Koła Wiedeńskiego wyszła tzw. emotywna koncepcja znaczenia ocen i norm, czyli wypowiedzi niepoznawczych, komunikujących wartości, które nie są obserwowalne empirycznie, jednak służą komunikowaniu przeżyć emocjonalnych i postaw. W języku prawnym chodzi mianowicie o postawę komunikowania powinności i należności w zdaniach normatywnych.

W analizie sytuacji mówienia stosuje się założenia kontekstualizmu logicznojęzykowego. Reguły użycia wyrażeń traktuje się jako znaczenie znaku językowego wskazujące właściwy wybór zachowania językowego. Do opisu języka wprowadza się parametry pragmatyczne, takie jak nadawca, odbiorca i cel komunikacyjny w procesie interakcji społecznej. Zwykłą analizę semantyczną, polegającą na badaniu predykatywnej struktury zdania, poszerza się o badanie językowego aktu mowy i kontekstu, w którym

\footnotetext{
${ }^{35}$ Na temat operacji derywacyjnych w makrostrukturze tekstu, zob. Duszak 1998: 188.
} 
został on wykonany. Na akt mowy składa się funkcja pragmatyczna przekazu informacji oraz zbiór różnych elementów wiedzy i poglądów dostępnych nadawcy i odbiorcy.

W lingwistyce dialogu metodą jest rekonstrukcja podtekstu przez wypełnienie elementów języka brakujących w wypowiedzi, lecz których sens jest wyrażony w sposób niejawny, podtekstowy (implicite). To, co jest wyrażone w sposób jawny, tekstowy (explicite) należy do systemu języka. Zasadą redakcyjną jest budowanie zdań przepisu prawnego z pominięciem jednego lub więcej argumentów zdaniowych, których na podstawie kontekstu czy konsytuacji łatwo można się domyślić, por. przepis prawny w Konstytucji Rzeczypospolitej Polskiej oraz interpolacja tego przepisu w tabeli

Tabela 2. Przepis prawny i jego interpolacja:

\begin{tabular}{|l|l|}
\hline konstytucja RP (art. 31) & interpolacja przepisu prawnego \\
\hline Wolność czlowieka & $\begin{array}{l}\text { 1) Każdy człowiek jest wolny. } \\
\text { podlega ochronie prawnej }\end{array}$ \\
& $\begin{array}{l}\text { 2) Człowiek ma prawo do ochrony swojej wolności. } \\
\text { człowieka. }\end{array}$ \\
\hline
\end{tabular}

Ważnym założeniem lingwistyki jest, że każda nowa informacja w tekście prawnym, przekazana za pomocą środków językowych, jest wbudowana w informację stara. Inferencja wydobywa sensy należące do założonej presupozycji oraz wykrywa sensy należące do informacji nowej, implikowanej. Implikatury to treści semantyczne i pragmatyczne, które nie wynikają bezpośrednio z elementów leksykalno-strukturalnych wypowiedzi, lecz pośrednio są wydobywane dzięki zabiegom inferencyjnym (Paul Grice). Inferencja w stylistycznej strukturze języka prawnego dotyczy relacji między modalnością językową a stopniem wiarygodności danej propozycji na płaszczyźnie wiedzy prawniczej, która jest podstawą rozumienia informacji.

3.4. Składniki semantyczne i technika użycia znaków językowych w wypowiedzi prawnej decydują o odniesieniu znaków językowych do rzeczywistości pozajęzykowej, a także o stylu języka prawnego. Podmiot, orzeczenie i dopełnienie jako pojedyncze wyrazy lub wyrażenia wielowyrazowe wskazuja na osoby, ich czyny oraz na rzeczy. W systemie języka kategorię do przyporządkowań leksykalnych wyznaczają konwencje składniowe. Zdanie normatywne jest znakiem normy prawnej. Zdania opisowe stanowia obudowę zdania normatywnego - komunikują o warunkach i okolicznościach obowiązywania norm prawnych. Najbardziej złożonymi znakami języka prawnego są teksty prawne: kodeks, ustawa, rozporządzenie.

Do komunikowania treści prawnych nadawca tekstu prawnego adaptuje model komunikacyjny języka naturalnego, etnicznego. Znaki językowe czyni symbolami na mocy swego przyporządkowania do pojęć prawnych i sądów normatywnych. Jako symptomy znaki języka prawnego wyrażają stan wewnętrzny ustawodawcy, a jako sygnały są apelem do adresatów norm i sterują ich postępowaniem. Przyporządkowanie znaków konwencjonalnych - słów, zdań i tekstów - do znaków naturalnych, jakimi są 
pojęcia prawne, sądy normatywne i zbiory sądów normatywnych, następuje wyłącznie na mocy konwencji opartej na wiedzy prawniczej ${ }^{36}$.

Do systemowych kategorii języka prawnego należy egocentryczny układ wyrażeń w tekście, gramatyczna budowa zdań, sposoby wyrażania modalności oraz wskazywanie deiktyczne. W ramach tego samego systemu semiotycznego powtarzają się sformalizowane klisze składniowe przepisów prawnych, którymi ustawodawca ustanawia normy regulujące postępowanie podmiotów prawnych. Stylistyczna postać przepisu prawnego zależy od tego, czy wysłowiona norma reguluje stosunki prawne władcze w sposób kategoryczny według reguły: Ustanawiam, niech będzie $Z$, czy stosunki prawne zobowiązaniowe według reguły: Jeżeli zachodzi sytuacja p, to powinna nastapić sytuacja $q^{37}$.

Budowa gramatyczna i semantyka tekstu aktu normatywnego ma nacechowanie stylistyczne, które można potraktować jako znak indeksalny tekstu prawnego. W konkretnych przepisach prawnych konieczne jest wyzerowanie niektórych składników klisz składniowych, czyli zastosowania elipsy składniowej, ze względu na komunikatywność tekstu. Dlatego odczytanie z przepisów prawnych norm prawnych wymaga uzupełnienia fragmentów ukrytych lub skondensowanych w zwrotach różnie redagowanych.

3.5. Odniesienie znaków języka naturalnego do pojęć prawniczych i sądów normatywnych odkrywa badacz na podstawie konotacji istotnych dla funkcji komunikacyjnej języka prawnego. Konotacje te przedstawiaja językowy obraz świata norm prawnych w definicjach takich pojęć, jak stosunek prawny, norma prawna i przepis prawny, odpowiedzialność prawna, obowiązywanie prawa oraz porządek prawny, posługując się także bardziej szczegółowymi terminami prawniczymi. Pojęcia te tworzą pole semantyczne prawa. Zob. tabela 3.

Tabela 3. Pole leksykalno-semantyczne prawa w prawoznawstwie.

\begin{tabular}{|l|l|}
\hline pojęcia i terminy podstawowe & pojęcia i terminy podporządkowane \\
\hline stosunek prawny & $\begin{array}{l}\text { strony stosunku prawnego, obowiazki i możność działania stron, } \\
\text { przedmiot stosunku prawnego, przedmiot sporny, fakty prawne }\end{array}$ \\
\hline normy prawna \\
i przepis prawny & $\begin{array}{l}\text { podmioty normy prawnej: adresat normy i recipient działania } \\
\text { nakazanego przez normę, problem do rozstrzygnięcia, } \\
\text { przedmiot rzeczywisty regulacji normatywnej, } \\
\text { obowiązek, prawna możność działania i prawna wolność } \\
\text { działania, prawo podmiotowe, uprawnienie } \\
\text { wykładniki wartościujące postępowanie podmiotów: } \\
\text { powinność i należność }\end{array}$ \\
\hline odpowiedzialność prawna & wina i kara \\
\hline obowiązywanie prawa & ochrona praw podmiotowych; sąd \\
\hline porządek prawny & praworządność \\
\hline
\end{tabular}

\footnotetext{
${ }^{36}$ Por. model języka naturalnego jako organonu, Bühler 2004: 29. Zob. szerzej na temat teorii znaku i teorii komunikowania w języku prawnym, Lizisowa 2010: 53-56.

${ }^{37}$ Zob. sposoby wyrażania normy prawnej, Zieliński 1996: 69-90.
} 
Maria Teresa LIZISOWA, Metody badania języka prawnego wobec ...

Słowa przepisu prawnego odnosi więc badacz do znaków naturalnych, czyli do pojęć. Według teoretyków prawa stosunek prawny jest pierwszym pojęciem prawniczym organizującym siatkę pozostałych pojęć. Elementami stosunku prawnego są strony: zobowiązany i uprawniony, ich skorelowane obowiązki oraz prawna możność działania i prawna wolność działania, w tym uprawnienia, kompetencje, wolności prawnie chronione, roszczenia i inne prawa podmiotowe. Dalszymi elementami stosunku prawnego są przedmiot stosunku prawnego jako problem do rozstrzygnięcia w regulacji prawnej, przedmiot sporny jako przedmiot rzeczywisty regulacji prawnej, a także fakty prawne jako relacje interpersonalne między podmiotami. Stosunek prawny zachodzi między osobą zobowiązaną do pewnego postępowania przez normę prawną i osobą uprawnioną do wykonania czynności aktualizującej jej uprawnienia. Normy prawne to treści przepisów prawnych cechujące się tym, że zmierzają do czyjegoś władztwa, stawiając w sytuacji przymusowej adresata normy oraz dozwalając na aktualizację uprawnień recipienta działania nakazanego przez normę. Norma prawna wyznacza jednemu z podmiotów obowiązek postępowania w taki a taki sposób, gdy podmiot inny dokona czynności określonej przepisami prawa, które dozwalają jej, zabraniaja lub nakazuja prawną możność działania, tj. kompetencje czy upoważnienie, lub prawną wolność działania, tj. roszczenie. Zakres wolności prawnej podmiotu przysługuje temu podmiotowi jako zabezpieczona przez prawo podmiotowe możność działania i prawna wolność działania, czyli uprawnienie. Pojęcie stosunku prawnego nie jest pojęciem prostym ani jednolitym. Na gruncie prawa zobowiązań wyróżnia się stosunki zobowiązaniowe regulujące obowiązki i uprawnienia stron. Ze względu na pozycję stron wyróżnia się stosunki władcze wynikające $z$ kompetencji władzy. Ze stosunkiem prawnym wiąże się pojęcie odpowiedzialności prawnej, a to z kolei z pojęciem winy. $Z$ normą prawną wiąże się obowiązywanie prawa, ochrona praw podmiotowych i pojęcie sądu. Wyznaczony przez system norm prawnych układ organów, instytucji i procedur rozstrzygania określonych spraw dotyczących postępowania podmiotów prawnych stanowi porządek prawny. Gdy porządek prawny przybiera charakter podporządkowania się normie prawnej, mówi się wówczas o praworządności ${ }^{38}$.

Aby zidentyfikować semantykę słów w języku prawnym, trzeba wskazać na pojęcia $\mathrm{i}$ terminy $\mathrm{w}$ polu semantycznym prawo, takie jak norma prawna i przepis prawny, także na pojęcia i terminy podporządkowane tym pierwszym terminom podstawowym, takim jak podmioty normy prawnej, problem do rozstrzygnięcia i przedmiot sporny regulacji normatywnej. Trzeba też zidentyfikować semantykę wykładników modalnych. Następnie słowa języka ogólnego lub specjalistycznego w danej dziedzinie prawa (tu prawa cywilnego) i odpowiadające tym słowom ogólne pojęcia prawnicze, należy odnieść do rzeczywistości prawnej, którą ustawodawca reglamentuje $\mathrm{e}^{39}$.

\footnotetext{
${ }^{38}$ Zob. Lang [i in.] 1986, rozdz. 18; Z. Ziembiński 1980, rozdz. 6.

${ }^{39}$ Zob. Tematyzacja w strukturach składniowych języka prawnego, Lizisowa 2010: 61-6
} 
3.6. Odniesienie znaków języka prawnego do rzeczywistości prawnej, reglamentowanej przez ustawodawcę, językoznawca może badać metodami gramatyki generatywnej. Model systemu języka prawnego ma bazę składniową języka ogólnego. Wytworem bazy - jak twierdził Noam Chomsky (1928-) - jest zbiór struktur głębokich, dla których reguły semantyczne wyznaczają zbiór interpretacji semantycznych. Materiałem empirycznym do badania składniowych struktur głębokich w systemie języka prawnego jest zbiór struktur powierzchniowych potwierdzonych $\mathrm{w}$ zdaniach składających się na przepisy prawne. W strukturze powierzchniowej zdań przepisów prawnych badacz odkrywa strukturę głęboka, czyli wszystkie składniki semantyczne, jak również ich odniesienie do pojęć prawnych i sądów normatywnych, tj. dyspozycję w formie zdania normatywnego (nadrzędnego), $\mathrm{z}$ predykatem modalnym, $\mathrm{z}$ dwoma argumentami osobowymi i z argumentem rzeczowym. Na przykład w przepisie prawnym [Z] jako w złożonym znaku języka prawnego wyodrębnia zdania normatywne [N], czyli dyspozycję. Wyodrębnia też zdania opisowe, podrzędne, warunkowe [O], czyli hipotezę:

Art. 42. $\$ 1$. Jeżeli osoba prawna nie może prowadzić swoich spraw z braku powołanych do tego organów [O], sąd ustanawia dla niej kuratora [N].

§2. Kurator powinien postarać się niezwłocznie o powołanie organów osoby prawnej [N], a w razie potrzeby o jej likwidacje [N].

W zdaniach normatywnych $[\mathrm{N}]$ wyodrębnia znaki proste $[\mathrm{X}],[\mathrm{C}],[\mathrm{Y}],[\mathrm{R}]$ :

$[\ldots]$ sąd $[\mathrm{X}]$ ustanawia $[\mathrm{C}]$ dla niej $[\mathrm{Y}]$ kuratora $[\mathrm{R}]$.

Kurator $[\mathrm{X}]$ powinien postarać się niezwłocznie $[\mathrm{C}]$ o powołanie organów $[\mathrm{R}]$ osoby prawnej $[\mathrm{Y}] \ldots$,

$\mathrm{Z}=$ przepis prawny jako znak językowy

$\mathrm{N}=$ zdanie normatywne

$\mathrm{O}=$ zdanie opisowe

$\mathrm{X}=$ adresat normy prawnej

$\mathrm{Y}=$ recipient działania ustanowionego przepisem prawnym

$\mathrm{C}=$ czyn ustanowiony przepisem prawnym

$\mathrm{R}=$ przedmiot stosunku prawnego jako problem do rozstrzygnięcia

Rekonstruuje więc strukturę głęboką przepisu prawnego, która jest następująca:

$\mathrm{Z}=[\mathrm{O}]+[\mathrm{N}=(\mathrm{X}+\mathrm{C}+\mathrm{Y}+\mathrm{R})]$

Tak więc, ze struktur powierzchniowych przepisów prawnych, które są zdaniami eliptycznymi, generuje struktury głębokie zdań normatywnych i opisowych, oddzielając normatywne dyrektywy sensu, wiążące deskryptywnie znaczenie normy z normatywna rzeczywistością, jak również odnosi rzeczywistość normatywną do rzeczywistości programowanej przez ustawodawcę $\mathrm{w}$ realnym świecie. Tworząc model struktury głębokiej zdania normatywnego, badacz rozpoznaje w układzie znaków językowych predykat modalny [np. czasowniki niefleksyjne powinien, może, ma prawo + bezokolicznik, albo ich ekwiwalenty tekstowe, jak forma czasownika ustanawia użytego 
w 3 os. czasu teraźniejszego; inne wyrażenia, np. niezwłacznie nie są obligatoryjne w zdaniu normatywnym - ważne są jednak ze względu na to, że uściślają okoliczności obowiązywania normy prawnej wysłowionej przepisem prawnym], a także konotowane przez ten predykat argumenty osobowe i przedmiotowe, które wskazuja, kto, co powinien czynić, na kogo może być skierowane pole działania oraz co jest przedmiotem spornym $\mathrm{w}$ regulacji normatywnej. Brakujące w przepisie prawnym elementy normy prawnej podlegaja $\mathrm{w}$ wykładni przepisu prawnego interpolacji, czyli uzupełnieniu na podstawie wiedzy prawniczej. Rozpoznaniu badacza podlegają zatem elementy języka, które spełniają funkcję illokucyjną stanowienia danej normy prawnej oraz elementy języka opisowe, których funkcją illokucyjna jest powiadamianie o warunkach i okolicznościach obowiązywania tej właśnie normy prawnej, a które mają charakter poznawczy w rzeczywistości normatywnej i w realnym świecie.

3.7. Byt prawa tworzą idealne modele konstruktów mentalnych norm prawnych wysłowionych $\mathrm{w}$ przepisach prawnych, przedstawiajace stosunki prawne tetyczne. W rzeczywistości prawnej abstrakcyjny byt prawa ukonkretnia się w realnych stosunkach prawnych jako prawa podmiotowe konkretnych osób. Znaki językowe przedstawiaja podmiotowi poznającemu pojęcia prawne i sądy normatywne, jak również realną rzeczywistość. W obu przypadkach mówi się, że ktoś ma jakieś prawo do czegoś - albo teoretycznie, albo praktycznie. Badacz odkrywa elementarne struktury rozumowania, według których zgodnie $\mathrm{z}$ tradycją $\mathrm{i}$ kultura prawną teksty prawne są tworzone przez ustawodawcę $\mathrm{i}$ interpretowane $\mathrm{w}$ odbiorze ${ }^{40}$. Relację między wyrażeniami języka a odniesieniem wyrażeń języka naturalnego do pojęć prawnych, bytów językowych i bytów rzeczywistych odkrywa metodami onomazjologii i semazjologii. Przykłady przedstawione w tabeli 3. ilustrują relację wyrażeń języka do pojęć prawnych i sądów normatywnych oraz do bytów językowych i bytów rzeczywistych. Zob. tabela

${ }^{40}$ Szczegółowe zasady techniki legislacyjnej i wykładni prawniczej są unormowane ustawowo (zob. Rozporządzenie Prezesa rady Ministrów z dnia 20 czerwca 2002 r. w sprawie „Zasad techniki prawodawczej” Dz. U. z dnia 5 lipca 2002 r.), są też przedmiotem badań naukowych oraz nauczania na studiach prawniczych. Teoretyczne ujęcie wykładni prawa, charakterystyka właściwości polskich tekstów prawnych, teoretyczne podstawy derywacyjnej koncepcji postepowania interpretacyjnego oraz dyrektywy postępowania interpretacyjnego zmierzajace do odtworzenia z przepisu prawnego wysłowionej w nim normy postępowania, zob. Zieliński 2002. 
Tabela Odniesienie wyrażeń języka naturalnego do pojęć prawnych.

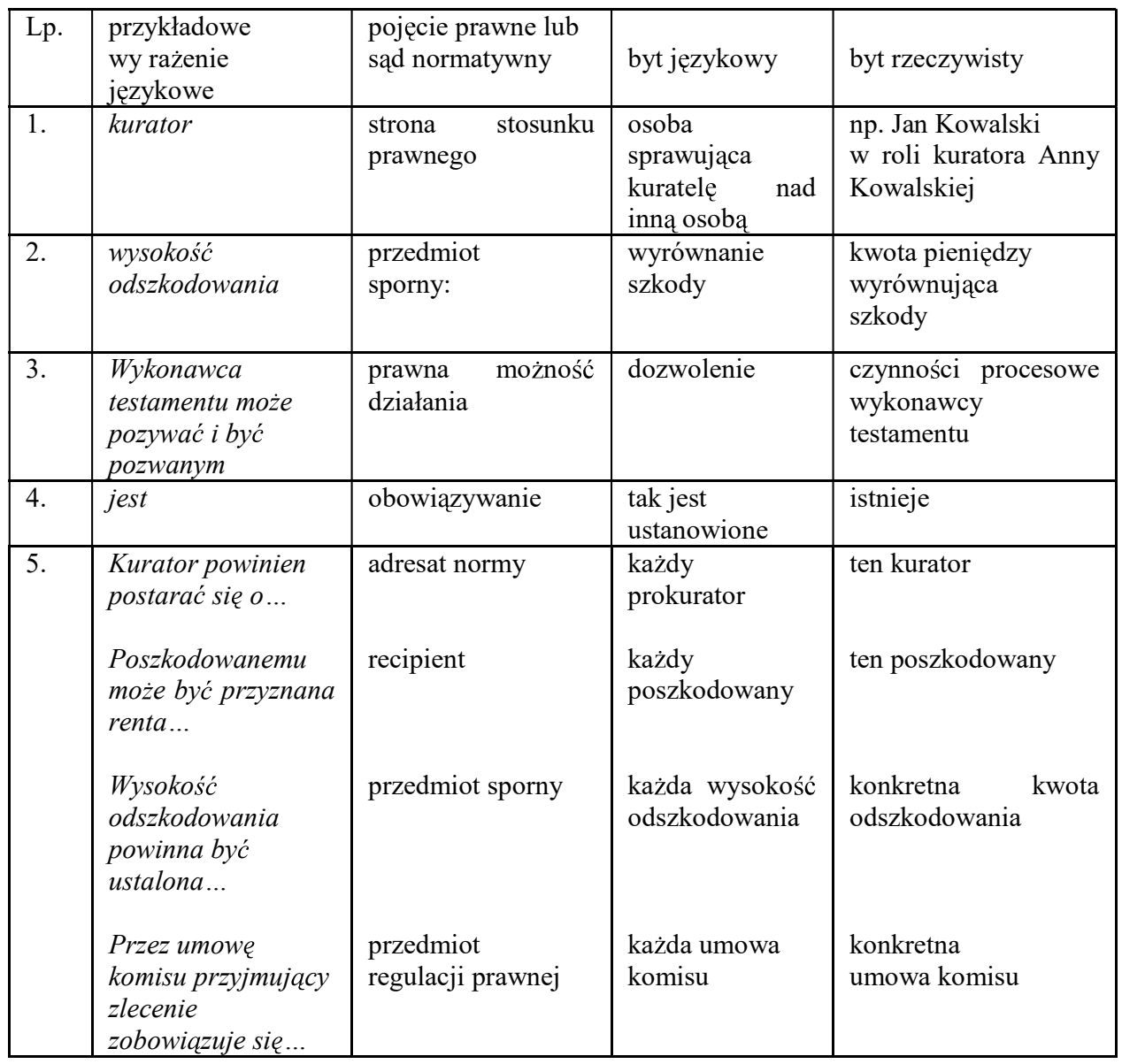

Tabela ilustruje semantykę wyrażeń, polach znaczeniowe klas wyrazów, związki struktur języka prawnego ze strukturą rzeczywistości prawnej oraz modyfikację znaczenia wyrażeń pod wpływem kontekstu.

1) Analiza pierwszego przykładu pokazuje redukcję uniwersaliów w języku prawnym do przedmiotów jednostkowych, istniejących fizycznie. Znaczenie nazw ogólnych, którym odpowiadają pojęcia prawne, zależy od tego, do czego się odnosza, np. w Kodeksie cywilnym odpowiednikiem nazwy ogólnej kurator jest 'osoba fizyczna ustanowiona postanowieniem sądu do sprawowania kurateli', czyli byt językowy mający jedynie cechy wspólne danej klasie przedmiotów konkretnych (uniwersaliów), por. w przepisie: „Jeżeli osoba prawna nie może prowadzić swoich spraw z braku powołanych do tego organów, sad ustanawia dla niej kuratora” (art. 42. § 1.). Natomiast odpowiednikiem tej samej nazwy ogólnej w rzeczywistości pozajęzykowej może być 
Maria Teresa LIZISOWA, Metody badania języka prawnego wobec ...

poszczególna osoba ludzka (powszechnik) jako jednostkowy byt istniejący fizycznie, np. pot. Jan Kowalski jest kuratorem Anny Kowalskiej). Według pluralistycznej koncepcji znaczenia F. H. Bradleya występuje tu dualizm uniwersaliów i przedmiotów jednostkowych pozostających w relacji zewnętrznej ${ }^{41}$.

2) W przykładzie drugim badacz szuka bezpośredniego związku między wyrażeniem języka, bytem językowym i tekstowym, bytem rzeczywistym w stosunkach społecznych oraz pojęciem prawniczym, np. w przepisie: „wysokość odszkodowania powinna być ustalona wedlug cen $z$ daty ustalenia odszkodowania" (art. $363 \S 2 \mathrm{k}$. c.) wysokość odszkodowania to 1) 'przedmiot sporny' 2) 'nazwa abstrakcyjna w funkcji przydawki, wskazująca na wyrównanie szkody majątkowej'; 3) 'kwota pieniędzy wyrównująca szkody, ustalona według cen z daty ustalenia odszkodowania'.

3) Semantyka wyrazu obejmuje także badanie pól znaczeniowych. Pola znaczeniowe i odpowiadające im pola pojęciowe w semantyce strukturalnej bada się woparciu o relacyjną strukturę języka opartą na łączliwości jednostek języka w związkach paradygmatycznych w obrębie tej samej klasy wyrazów (rzeczowników, zaimków, czasowników itp.) w różnych kontekstach (Johst Trier 1894-1970) oraz w związkach syntagmatycznych opartych na relacjach sensu wobrębie wyrażeń połączonych składniowo w tym samym kontekście w obrębie kolokacji (Walter Porzig), w których zasadniczą wagę mają dwuczłonowe przeciwstawienia, na przykład opozycje komplenentarności, charakterystyczne z tego względu, że zaprzeczenie jednego wyrazu powoduje stwierdzenie drugiego, jak pozywać - być pozwanym 'czynności procesowe w procesie cywilnym' w przykładzie trzecim, por. „Wykonawca testamentu może pozywać $i$ być pozywany $w$ sprawach wynikajacych z zarzadu spadkiem. " (art. 988. $\S 1$. k.c).

4) W przykładzie czwartym charakterystyczne dla języka prawnego ograniczenie znaczenia czasownika jest 'istnieje', jak w przepisie: „Miejscem zamieszkania osoby fizycznej jest miejscowość, w której osoba ta przebywa z zamiarem statego pobytu" (art. 25 k.c.), następuje w zdaniu normatywnym do "tak jest ustanowione i obowiązuje', W języku zachodzi bowiem zjawisko zyskiwania przez wyraz wartości znaczeniowej pod wpływem ustabilizowanego kontekstu.

5) Zakłada się, że na podstawie struktur języka prawnego można wnioskować o strukturze rzeczywistości prawnej. Sformułowanie teorii mechanizmów spójnościowych tekstów dało szansę rozróżnienia tematu wypowiedzi jako punktu wyjścia oraz rematu wypowiedzi, który wprowadza to, o czym w temacie się orzeka. Aktualne rozczłonkowanie zdania może, ale nie musi odpowiadać formalnemu podmiotowi i orzeczeniu w zdaniu (Vilém Mathesius 1882-1945). Organizacja przepisu prawnego w warstwie stylistycznej służy wprowadzeniu tematu komunikowania w różnych modelach zdań normatywnych, które można potraktować jako subsystemy

\footnotetext{
${ }^{41}$ Francis Herbert Bradley (1846-1924) zauważył, że wyrażenia języka mają znaczenie wtedy, gdy istnieje coś, do czego się odnoszą i według teorii relacji wewnętrznych zbudował on pluralistyczną koncepcję rzeczywistości oraz referencyjną teorię zdań. Ta pluralistyczna koncepcja znaczenia zakładała dualizm uniwersaliów i przedmiotów jednostkowych pozostających w relacji zewnętrznej.
} 
składniowego systemu zdań normatywnych w języku prawnym. Na przykład, w zdaniu: „Kurator powinien postarać się niezwłocznie o powolanie organów osoby prawnej”, (art. 42. § 1. k.c.) mianownikowa forma rzeczownika osobowego kurator w funkcji podmiotu deskryptywnie wskazuje na kuratora jako adresata normy prawnej. Natomiast w przepisie tegoż kodeksu: „poszkodowanemu może być przyznana renta tymczasowa” (art. $444 \S 1$. k.c.) celownikowa forma rzeczownika poszkodowanemu w funkcji dopełnienia deskryptywnie wskazuje poszkodowanego jako recipienta działania ustanowionego tym przepisem. W przepisie: „,W]ysokość odszkodowania powinna być ustalona wedlug cen $z$ daty ustalenia odszkodowania, chyba że szczególne okoliczności wymagaja przyjęcia za podstawe cen istniejacych w innej chwili” (art. $363 \S 2$ k. c.) mianownikowa forma podmiotu wysokość odszkodowania wskazuje na przedmiot sporny prawnej. Natomiast w przepisie: „Przez umowe komisu przyjmujacy zlecenie [...] zobowiazuje się [...] do kupna lub sprzedaży” art. 765 k. c. [5] wyrażenie przez umowe komisu w funkcji dopełnienia komunikuje, że umowa komisu jest przedmiotem podlegającym regulacji prawej.

Rozpoznanie semantyki wyrażeń w języku prawnym polega na wyodrębnieniu naturalnych znaków, jakimi są pojęcia prawnicze i sądy normatywne, a następnie na odniesieniu znaków naturalnych do znaków języka zakodowanych w tekście prawnym, jakimi są rzeczy abstrakcyjne, czyli normy prawne jako wypowiedzi w języku prawnym oraz normy prawne jako reguły postępowania w rzeczywistych sytuacjach prawnych. Zob. rys 5.

Rys. 5. Zdanie normatywne i jego składniki jako znaki naturalne i znaki językowe.

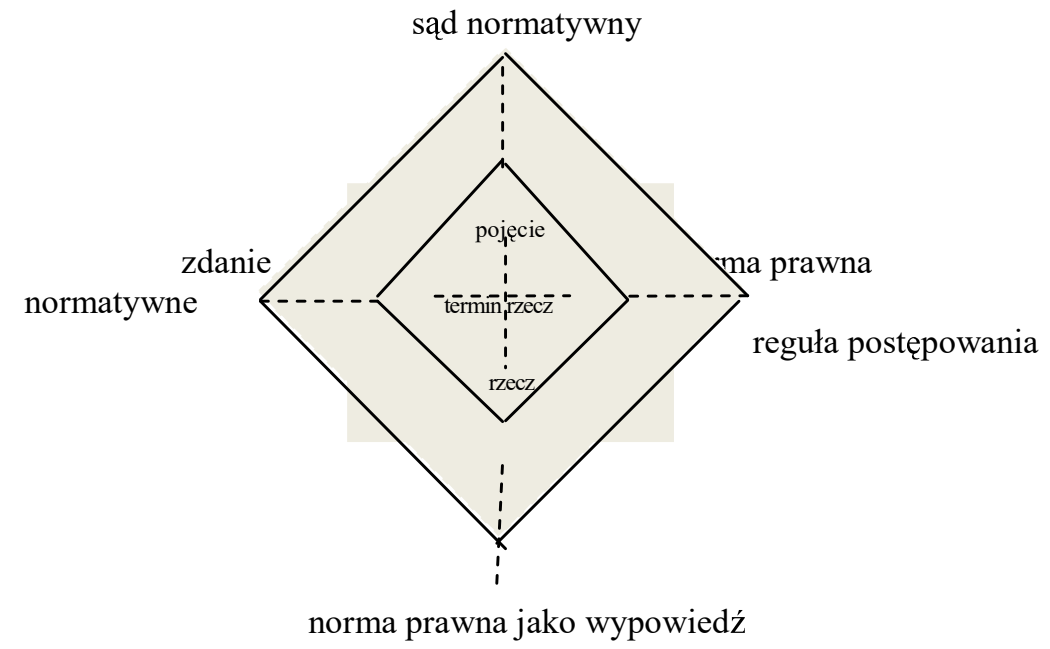

Badacz identyfikuje znaki języka prawnego, które odnoszą się do idealnych tworów przedstawiających przedmioty, zdarzenia i przeżycia jako elementy norm prawnych ustanowionych przez ustawodawcę w postaci przepisów prawnych. Ten świat 
Maria Teresa LIZISOWA, Metody badania języka prawnego wobec ...

tekstu konfrontuje następnie z obiektywnym światem przedmiotów i zdarzeń dających się zlokalizować przestrzennie i czasowo, dostępnych doświadczeniu ustawodawcy i czytelnikowi aktu normatywnego. Analiza gramatyki zdania normatywnego jest kluczem do przedstawienia teorii języka prawnego.

Analiza tekstów języka prawnego, w których zawarty jest język prawny jako twór mowy społeczny i abstrakcyjny, potwierdza główną tezą Bronisława Wróblewskiego, że rzeczywistość prawna istnieje niezależnie od ustawodawcy, jest dziedziną życia politycznego, społecznego, gospodarczego czy kulturalnego, jak również tezę, że istnieje rzeczywistość prawna ustanowiona jako system norm prawnych, ,językiem codziennym z dodaniem pewnego rodzaju gwary, którą można nazwać - prawną”. Gwara ta ,jest materiałem, z którego również czerpie ustawodawca, nadając mu takie sformułowania, których domaga się technika języka prawnego". Materiał rzeczywistości prawnej jest przez ustawodawcę tylko reglamentowany w tym sensie, że działa on ,jako konstruktor tego, co będzie się działo pod znakiem powinności”42.

\section{Wnioski}

Analiza lingwistyczna tekstów prawnych zmierza do wyodrębnienia systemu form znaków języka prawnego, wyodrębnionych z systemu znaków języka etnicznego. Badacz odtwarza strategie dostosowania znaków języka powszechnego i języków swoistych, rodzajowo określonych, do struktury semiotycznej wypowiedzi normatywnej, jaką jest przepis prawny. Kodem semiotycznym dla językoznawcy jest także styl tekstu prawnego, związany bezpośrednio z kulturą prawa stanowionego, wszak styl tworzą struktury wypowiedzi o specyficznym charakterze performatywnym, modalnym i logicznosemantycznym. Badacz traktuje język prawny jako zbiór idealnych modeli oraz jako ich tekstowa realizację $\mathrm{w}$ toku formułowania przez ustawodawcę performatywnych wypowiedzi nakazujących i modalnych wypowiedzi projektujących odbiór tekstu. Opisuje zatem transpozycję struktury wzorca tekstowego, aktualizowanego w konkretnych tekstach, do jednostek wypowiedzi w aspekcie illokucyjnym $\mathrm{z}$ pozycji nadawcy, a także bada reinterpretacje $\mathrm{w}$ odbiorze jednostek wypowiedzi ze wzorca tekstowego w aspekcie perlokucyjnym z pozycji odbiorcy. Opis alternatyw stylistycznych zmierza do pozyskania wiedzy na temat odniesienia znaków desygnujących kto, dla kogo, ze względu na co, pod jakim warunkiem i w jakich okolicznościach ustanawia określony sposób działania podmiotów i jak kwalifikuje ich czyny, co służy wykładni językowej przepisów prawnych. Z punktu widzenia teorii języka badacz charakteryzuje osobliwy system form znaków w strukturze języka prawnego, wywnioskowany dzięki analizie tekstów prawnych.

Punktem wyjścia do opracowania teorii języka prawnego jest ontologiczny status prawa jako powinności i należności w relacjach interpersonalnych oraz jako rzeczywistości prawnej w aktach normatywnych i w prognozowanym przez ustawodawcę obrocie prawnym. Badacze - prawoznawca i lingwista - zmierzają do wyodrębnienia w języku prawnym formuł nakazu, zakazu i dozwolenia w odniesieniu do prawa

${ }^{42}$ Zob. Wróblewski 1948. 
podmiotowego, do wskazania formuł opisujących warunki i okoliczności obowiązywania prawa pozytywnego, podnoszą problem rytuału retoryczno-organizacyjnego i kompozycji tekstu pisanego w języku prawnym.

Język prawny jest badany jako langue i competence języka etnicznego, jak i w sferze użycia jako parole, performance w tekstach prawnych i w dyskursie obsługującym dziedzinę prawa stanowionego. Zatem badaniom, wzajemnie uzupełniającym się z perspektywy prawniczej i lingwistycznej, podlega idealny model języka ustawodawcy, będący konstruktem mentalnym. Badacz opisuje formy znaków językowych powodujące różnicowanie systemowe. Przedstawia mentalne modele znaków naturalnych, pojęć i sądów prawniczych oraz zjawisko penetracji systemów form znaków językowych w wielu językach przedmiotowych będących funkcjonalnymi wariantami języka etnicznego, gdyż $z$ nich ustawodawca czerpie te formy i przystosowuje je do swojego języka. Bada też styl tekstu prawnego jako znak indeksalny języka prawnego. 


\section{Bibliografia}

Austin, John, Langshaw. 1993. Mówienie i poznanie. Rozprawy i wykłady filozoficzne. Warszawa: Wydawnictwo Naukowe PWN.

Bator, Andrzej, Włodzimierz Gromski, Artur Kozak, Stanisław Kaźmierczyk, Zbigniew Pulka 2006. Wprowadzenie do nauk prawnych. Leksykon tematyczny. Warszawa: Wydawnictwo Prawnicze LexisNexis.

Bühler, Karl. 200 Teoria języka. o językowej funkcji przedstawiania. Kraków: Universitas.

Choduń, Agnieszka. 2007. Stownictwo tekstów aktów prawnych w zasobie leksykalnym współczesnej polszczyzny. Warszawa: Wydawnictwo trio.

Duszak, Anna. 1998. Tekst, dyskurs, komunikacja międzykulturowa, Warszawa: PWN.

Gizbert-Studnicki, Tomasz. 1979. Czy istnieje jezyk prawny, Państwo i Prawo, nr 3, ss. 49-60.

Gizbert-Studnicki, Tomasz. 1986. Język prawny z perspektywy socjolingwistycznej, Warszawa/Kraków: PWN.

Grabias, Stanisław. 199 Język w zachowaniach społecznych, Lublin: Wydawnictwo UMCS.

Grucza, Franciszek. 1997. Języki ludzkie a wyrażenia językowe, wiedza a informacja, mózg a umysł ludzki, W Podejścia kognitywne $w$ lingwistyce, translatoryce $i$ glottodydaktyce, red. F. Grucza i M. Dakowska, Warszawa: Wydawnictwo Uniwersytetu Warszawskiego.

Grzybowski, Stefan. 1961. Wypowiedź normatywna i jej struktura formalna. Zeszyty Naukowe Uniwersytetu Jagiellońskiego. Rozprawy i Studia, t. 39. Kraków.

Habermas, Jürgen. 2005. Faktyczność i obowiązywanie. Teoria dyskursu wobec zagadnień prawa i demokratycznego państwa prawa. Warszawa: Scholar.

Krapiec, Mieczysław Albert. 1975. Człowiek i prawo naturalne, Lublin:Wydawnictw KUL.

Lang Wiesław, Jerzy Wróblewski, Sylwester Zawadzki, 1986. Teoria państwa i prawa, Warszawa: PWN.

Lizisowa, Maria Teresa. 1995. Podstawowe terminy prawne staropolskie na tle słowiańskim. Studium semantyczne, Ktraków: Wydawnictwo Naukowe WSP w Krakowie.

Lizisowa, Maria Teresa. 2006. Tekst - kontekst - interpretacja. W poszukiwaniu semiotycznodyskursywnych wzorców konkretyzacji języka. Część pierwsza. Wybrane zagadnienia dyskursu prawnego, Kraków: Collegium Columbinum.

Lizisowa, Maria Teresa. 2000. Język Kodeksu Olszewskiego. Z recepcji staropolskiego języka prawno-sądowego $w$ Wielkim Księstwie Litewskim w szesnastym wieku. Kraków: Wydawnictwo Naukowe Akademii Pedagogicznej w Krakowie.

Lizisowa, Maria Teresa. 2002. Model komunikacji językowej w konstytucjach Rzeczypospolitej (relacja nadawca-odbiorca). Biuletyn Polskiego Towarzystwa Językoznawczego z. LVIII. Warszawa.

Lizisowa, Maria Teresa. 2008. Semantyka a struktura tekstu prawnego. [W:] Styl a semantyka, red. Irena Szczepankowska, Wydawnictwo Uniwersytetu w Białymstoku, Białystok 2008, 381-400.

Lizisowa, Maria Teresa. 2009. Performatywne wypowiedzi prawne w aspekcie lingwistyki tekstu. W Prawo i język. Red. Anna Mróz, Adam Niewiadomski, Monika Pawelec, 19-36. Warszawa: Zakład Graficzny Uniwersytetu Warszawskiego.

Lizisowa, Maria Teresa. 2010. Tekst prawny w teorii znaku i w teorii komunikowania. W Prawo, język, etyka, red. Adam Niewiadomski, Ewa Sztymelska, 51-66. Warszawa: Zakład Graficzny Uniwersytetu Warszawskieg.

Lizisowa, Maria Teresa. 2012. O formie i treści znaków języka prawnego. [W:] Język wspótczesnego prawa. Red. Adam Niewiadomski, Ewa Sztymelska, 15-41. Warszawa: Zakład Graficzny Uniwersytetu Warszawskiego. 
Malinowska, Ewa. 2012. Konstytucja jako gatunek tekstu prawnego. Opole: Wydawnictwo Uniwersytetu Opolskiego.

Malinowski, Andrzej. 2006. Polski język prawny. Wybrane zagadnienia. Warszawa: Wydawnictwo Prawnicze LexisNexis.

Milewski, Tadeusz. 1972. Językoznawstwo. Warszawa: PWN.

Opałek, Kazimierz. 197 Z teorii dyrektyw i norm. Warszawa: PWN.

Petzel, Jacek. 1999. Informatyka prawnicza. Zagadnienia teorii i praktyki, Warszawa.

Petzel, Jacek. 2006. Język prawny w świetle lingwistycznej teorii rejestru językowego, Studia Juridica XLV/2006, ss. 153-163. Warszawa.

Pieńkos, Jerzy. 1999. Podstawy juryslingwistyki. Język w prawie - prawo w języku, Warszawa: Muza SA Oficyna Prawnicza.

Sarkowicz, Ryszard. 1998. O rozumieniu spójności w interpretacji prawniczej. W Teoria prawa. Filozofia prawa. Wspótczesne prawo i prawoznawstwo. Roruń: Wydawnictwo UMK.

Szczepankowska, Irena. 200 Język prawny I Rzeczypospolitej w „Zbiorze praw sadowych” Andrzeja Zamoyskiego. I. Pojęcia prawne. II. Wypowiedzi normatywne. Biatystwok: Wydawnictwo Uniwersytetu w Białymstoku.

Tokarczyk, Roman. 200 Filozofia prawa. Lublin: Wydawnictwo UMCS.

Woleński, Jan. 1972. Logiczne problemy wykładni prawa. Zeszyty Naukowe UJ, Prace Prawnicze, z. 56. Kraków.

Wróblewski, Bronisław. 1948. Język prawny i prawniczy. Kraków: Drukarnia Uniwersytetu Jagiellońskiego.

Wróblewski, Jerzy. 1959. Zagadnienia teorii wyktadni prawa ludowego. Warszawa: Wydawnictwo Prawnicze.

Zajda, Aleksander. 2001. Staropolska terminologia prawnicza (do 1500 r.), Kraków: Uniwersytet Jagielloński.

Zajda, Aleksander. 1990. Studia z historii stownictwa prawniczego i frazeologii. Kraków: Wydawnictwo Uniwersytetu Jagiellońskiego.

Zieliński, Maciej. 1972. Interpretacja jako proces dekodowania tekstu prawnego. Prace Wydziału Prawa Uniwersytetu im. Adama Mickiewicza 54, Poznań

Zieliński, Maciej. 1992. [W:] Zygmunt Ziembiński, Maciej Zieliński, Dyrektywy i sposób ich wypowiadania,.69-90. Warszawa: Zakład Semiotyki Logicznej Uniwersytetu Warszawskiego.

Zieliński, Maciej. 2002. Wykładnia prawa. Zasady. Reguly. Wskazówki. Warszawa: Wydawnictwo Prawnicze LexisNexis.

Ziembiński, Zygmunt. 1966. Logiczne podstawy prawoznawstwa. Warszawa: Wydawnictwo Prawnicze.

Ziembiński, Zygmunt. 2002. Logika praktyczna. Warszawa: PWN.

Ziembiński, Zygmunt. 1980. Problemy podstawowe prawoznawstwa, Warszawa: PWN. 